\title{
PRODUCTION AND QUALITY OF FORAGE UNDER INTERCROPPING SYSTEMS IN THE CERRADO/PANTANAL ECOTONE
}

\author{
PRODUÇÃO E QUALIDADE DA FORRAGEM DE CONSÓRCIOS NO ECÓTONO \\ CERRADO/PANTANAL
}

\author{
Marcus Vinicius Morais de OLIVEIRA'; Andréia Alves DEMEU²; \\ Franscine Kelli Quinhones BONATTI³; Francisco Eduardo TORRES'; \\ Paulo Eduardo TEODORO ${ }^{4}$
}

1. Universidade Estadual de Mato Grosso do Sul, Aquidauana, MS, Brasil; 2. Faculdades Integradas Aparício Carvalho, Porto Velho, RO, Brasil; 3. Bolsista FUNDECT, DCR, UEMS, Aquidauana, MS, Brasil; 4. Universidade Federal do Mato Grosso do Sul, Chapadão do Sul, MS, Brasil. eduteodoro@hotmail.com

\begin{abstract}
The aims of this study were to evaluate forage production and nutritional quality of the elephant grass, leucaena and pigeon pea beans, grown in monocrop or in intercropping systems in Cerrado / Pantanal ecotones in both, dry and rainy, seasons. Experimental design was completely randomized with five treatments and five repetitions. The treatments were: elephant grass, leucaena and pigeon pea all of these in monocrop; intercropping elephant grass with Leucaena; intercropping elephant grass with pigeon pea. During the rainy season, it was carried out three cuts at intervals of 60 days, and in the dry season a single cut with 180 days. In the rainy season, the biomass produced of the forages elephant grass, leucaena and pigeon pea corresponded respectively to $72,64,76 \%$ of the annual production. Under intercropping system, fodder behaves similarly, with the average of $72 \%$ of annual production. During this period, the nutritional quality of the forages was also higher than the dry season. In the dry period, there was decreased the production of biomass and a reduction in the proportion of leaves in all the forage, regardless of cultivation system. In both seasons (rainy and dry), the forage grown under intercropping system showed higher dry matter production in relation to monocrop system, with most of this production coming of elephant grass. The intercropping elephant grass with the pigeon pea has the highest production of dry matter, while the intercropping elephant grass with Leucaena has better nutritional quality.
\end{abstract}

KEYWORDS: Cajanus cajan. Pennisetum purpureum. Leucaena leucocephala.

\section{INTRODUCTION}

Pastures represent the most economical way to feed cattle, and may therefore be able to influence the costs involved with the herd. Good pastures substantially reduce substantially the need for concentrated supplements, which may increase the economic efficiency of the production system in turn (OLIVEIRA et al., 2014).

In tropical conditions, especially in the Midwest region of Brazil, the forage production shows a marked variation over the year (ABOT et al., 2015). Thus, in hot and rainy months, there is availability of pastures in quantity and quality; however, in cold and dry months, fodder become mature and present decline in vegetative growth, reduction in protein, minerals and soluble carbohydrates, and increase in indigestible fiber content, due to the physiological process of lignification. Consequently, there is weight loss and increased in the productivity of animals.

In this context, grasses are essential because it is a way for maintaining the nutritional balance of the animals. Among the tropical grasses used for this purpose, the elephant grass (Pennisetum purpureum) stands out for its high dry matter production $(\mathrm{Dm})$ per unit area, good nutritional value when harvested in appropriate age and good palatability, and resistance to unfavorable weather conditions, especially drought (CARNEIRO et al., 2006).

The intercropping grass and legume is also an alternative, since the legume can become an option for animal protein supplementation, besides fixing nitrogen into the soil and to favor the growth of grass in which it is intercropping. According to Seiffert and Thiago (1983), the tree and shrub species such as leucaena (Leucaena leucocephala) and pigeon pea (Cajanus cajan), respectively, are recommended for use by consortium, as besides the major forage potential, they are also more resistant to drought than herbaceous legumes because of their deeper root system.

Thus, the aims of this study were to evaluate forage production and nutritional quality of the elephant grass, leucaena and pigeon pea beans, grown in monocrop or in intercropping systems in Cerrado / Pantanal ecotones in both, dry and rainy, seasons. 


\section{MATERIAL AND METHODS}

The trial was conducted at the Mato Grosso do Sul State University (UEMS), campus of Aquidauana, MS, with geographic coordinates $20^{\circ} 28^{\prime} \mathrm{S}$ and $55^{\circ} 48^{\prime} \mathrm{W}$ and altitude of $149 \mathrm{~m}$. The weather is hot in summer, with average temperatures around $32^{\circ} \mathrm{C}$ and cold and dry in winter, averaging around $21^{\circ} \mathrm{C}$. The annual rainfall is between 1,000 and 1,400 mm, being December and January the rainiest months. Soils, mostly, are Ultisol Dystrophic, of low natural fertility.

Experimental design was completely randomized with five treatments and five repetitions. Treatments were: elephant grass in monocrop; leucaena in monocrop; pigeon pea in monocrop; intercropping elephant grass with Leucaena; intercropping elephant grass with pigeon pea. Sowing of forage occurred in December, in experimental plots of $40 \mathrm{~m}^{2}$ ( $\left.4 \times 10 \mathrm{~m}\right)$, ignoring 0.25 $\mathrm{m}$ on each side (borders). After being delimited the area of the plots, the forage were sowing in line. A total of six rows per plot with $70 \mathrm{~cm}$ distance from each other, the first line distance of $25 \mathrm{~cm}$ side.

Elephant grass planting was carried out through stalks from cv. Napier, placed in grooves and then cut into smaller pieces to allow a faster and more uniform bud sprouting. Subsequently, it were covered with a layer of soil about $15 \mathrm{~cm}$. Pigeon pea was sown directly into the holes, since the seeds of Leucaena were scarified with warm water $\left(75^{\circ} \mathrm{C}\right.$ for 5 min), and initially seeded into plastic bags (10 x 15 $\mathrm{cm})$. When completing 45 days after seedling emergence, the seedlings were transplanted to the plots and placed in holes with $15 \mathrm{~cm}$ deep.

Legumes cultivated in monocrop were planted in holes, 18 plants per row spaced between plants from $56 \mathrm{~cm}$. In intercropping plots elephant grass, legumes were planted between the rows of the grass, keeping the same spacing. Thus, in the intercropping plot there were 3 lines with the grass and 3 rows with the legume, with the same number of plants per row, i.e., 18 plants.

We carried out maintenance topdressing fertilization with phosphorous $\left(\mathrm{P}_{2} \mathrm{O}_{5}\right)$, potassium $\left(\mathrm{K}_{2} \mathrm{O}\right)$ and nitrogen $(\mathrm{N})$. Phosphorus was applied at the beginning of the rainy season, and potassium and nitrogen fertilizers after cutting the plants, totaling three applications during the rainy season and one application at the end of the dry season. The amount of $\mathrm{P}_{2} \mathrm{O}_{5}, \mathrm{~K}_{2} \mathrm{O}$ and $\mathrm{N}$ per plot was 1.2; 5.3 and $2.7 \mathrm{~kg}$, respectively.

Evaluation of fodder occurred in two stages. The first in the rainy season (October to March), and the second during the dry season (April to September). Firstly, standardization of the cutting was done 270 days after planting (September 30). During the rainy season was carried out three cuts at intervals of 60 days (November 30, January 30 to March 30). In the dry season it was performed only one cut at the end of the dry season, 180 days (September 30) after the last cut of the rainy season.

Morphological assessment of elephant grass, was carried out by cutting and separation of leaf blade, sheath more stem and senescent material from a clump per line. For legumes, we conducted the cutting and separation of fractions usable by the animal (leaves, stems smaller than $1 \mathrm{~cm}$ in diameter, and flower more pods) and not usable by the animal (stem larger than $1 \mathrm{~cm}$ diameter and senescent material) from one plant per line.

Determining the total dry matter (DM) production the plot was by cutting and weighing the plants that make up the useful area of the plot, adding in this the weight $(\mathrm{kg})$ of the plants used in the morphological assessment. Cutting plants were made $15 \mathrm{~cm}$ from the ground. After cutting and weighing, the materials of each plot (whole plant) was collected and stored at $-10^{\circ} \mathrm{C}$, except for plants that were used for the morphological separation.

In this case, in each plot, after morphologic separation and weighing, the plants fractions that formed the plot were mixed, sampled and then stored at $-10^{\circ} \mathrm{C}$. After the rainy period, a sample composed was made, referring to the three cutting. Subsequently, it was determined the dry matter $(\mathrm{DM})$, crude protein $(\mathrm{CP})$ and mineral matter $(\mathrm{MM})$ according to AOAC (1990) and neutral detergent fiber (NDF) according to Van Soest et al. (1991).

Data were subjected to analysis of variance and having significance for the F-test, $t$ means were compared by Tukey's test at 5\% probability. All analyses were performed with the free software $\mathrm{R}$ (R CORE TEAM, 2012).

\section{RESULTS AND DISCUSSION}

In the rainy seasons, the intercropping of the elephant grass with leucaena $(\mathrm{EG}+\mathrm{L})$ and the elephant grass with pigeon pea (EG+PP) had higher dry matter (DM) production (Table 1). This occurs, mainly, due to the high DM production of elephant grass, regardless of the form of cultivation (in intercropping or monocrop). Values in similar magnitudes were obtained by Queiroz Filho (2000), who observed DM production of $25.7 \mathrm{t} \mathrm{ha}^{-1}$ of the elephant grass in the cultivation monocrop in the rainy season. 
Table 1. Mean values for dry matter production $\left(\mathrm{kg} \mathrm{ha}^{-1}\right)$ of forage grass elephant (CE), Leucaena (L) and pigeon pea $(\mathrm{G})$ grown in monocrop and intercropping system during the rainy and dry season.

\begin{tabular}{lll}
\hline Forage & Rainy season & Dry season \\
\hline Elephant grass (EG) in monocrop & $20,269 \mathrm{~b}$ & $7,797 \mathrm{~b}$ \\
Leucaena (L) in monocrop & $6,407 \mathrm{c}$ & $3,640 \mathrm{c}$ \\
Pigeon pea (PP) in monocrop & $9,530 \mathrm{c}$ & $2,936 \mathrm{c}$ \\
Intercropping EG+L & $22,284 \mathrm{ab}$ & $8,479 \mathrm{~b}$ \\
Intercropping EG+L: Elephant grass & $21,910 \mathrm{~b}$ & $8,243 \mathrm{~b}$ \\
Intercropping EG+L: Leucaena & $373 \mathrm{e}$ & $236 \mathrm{e}$ \\
Intercropping EG+PP & $22,664 \mathrm{a}$ & $8,8670 \mathrm{a}$ \\
Intercropping EG+PP: Elephant grass & $20,830 \mathrm{~b}$ & $8,477 \mathrm{~b}$ \\
Intercropping EG+PP: Pigeon pea & $1,834 \mathrm{~d}$ & $393 \mathrm{~d}$ \\
\hline
\end{tabular}

Means followed by different letters in the column indicate significant differences according to Tukey's test at $5 \%$ probability.

Despite having shoed no statistical difference, it is important to report that the DM production of the elephant grass in these intercropping arrangements was superior to monocrop ones. Carneiro et al. (2006) verified a production of $23,4 \mathrm{t} \mathrm{ha}^{-1}$ in consortium $\mathrm{EG}+\mathrm{L}$ and attributed the high DM production to the biological $\mathrm{N}$ fixation by leguminous and the deep root system of the elephant grass. These benefits possibly provide greater DM production for the intercropping $\mathrm{EG}+\mathrm{PP}$ in dry season, that is characterized by having lower rainfall incidence and low temperatures'; reducing the growth and production of assimilates by the forage. The intercropping $\mathrm{EG}+\mathrm{L}$ also presents satisfactory DM production in the dry seasons, which shows that this modality can also be used by cattle farmers in the region with the advantage of Leucaena is a perennial leguminous, while the pigeon pea is a biannual species.

The elephant grass in monoculture and Leucaena grown in the intercropping EG+L showed the largest proportions of leaf during the rainy seasons (Table 2). The attainment of the high percentage of leaves by Leucaena in the intercropping $\mathrm{EG}+\mathrm{L}$ it is a characteristic which is favorable for the use of this modality because this legume has protein quality higher than the elephant grass. Other advantages are the smallest percentages of senescent material and stems lower and larger than $1 \mathrm{~cm}$, obtained by Leucaena in the consortium EG+L.

Table 2. Mean values for the percentage of leaves, culms, senescent material, stems lower and larger than $1 \mathrm{~cm}$ of forage grass elephant (CE), Leucaena (L) and pigeon pea $(\mathrm{G})$ grown in monocrop and intercropping system during the rainy season.

\begin{tabular}{llllll}
\hline Forage & Leaf & Culm & Senescent material & Stem $<1 \mathrm{~cm}$ & Stem $>1 \mathrm{~cm}$ \\
\hline Elephant grass (EG) in monocrop & $60.0 \mathrm{a}$ & $25.7 \mathrm{~b}$ & $14.3 \mathrm{a}$ & - & - \\
Leucaena (L) in monocrop & $50.0 \mathrm{bc}-$ & $0.0 \mathrm{~b}$ & $31.3 \mathrm{~b}$ & $18.8 \mathrm{a}$ \\
Pigeon pea (PP) in monocrop & $34.8 \mathrm{e}-$ & $17.4 \mathrm{a}$ & $43.5 \mathrm{a}$ & $4.3 \mathrm{~b}$ \\
Intercropping EG+L: Elephant grass & $46.3 \mathrm{~cd}$ & $37.3 \mathrm{a}$ & $16.4 \mathrm{a}$ & - & - \\
Intercropping EG+L: Leucaena & $66.7 \mathrm{a}-$ & $0.0 \mathrm{~b}$ & $33.3 \mathrm{~b}$ & $0.0 \mathrm{c}$ \\
Intercropping EG+PP: Elephant grass & $40.7 \mathrm{de}$ & $42.4 \mathrm{a}$ & $16.9 \mathrm{a}$ & - & - \\
Intercropping EG+PP: Pigeon pea & $54.5 \mathrm{bc}-$ & $0.0 \mathrm{~b}$ & $45.5 \mathrm{a}$ & $0.0 \mathrm{c}$ \\
\hline
\end{tabular}

Means followed by different letters in the column indicate significant differences according to Tukey's test at $5 \%$ probability.

In the dry seasons, the pigeon pea grown in intercropping $\mathrm{EG}+\mathrm{PP}$ had the highest proportion of leaves and low percentage of senescent material and stems lower and larger than $1 \mathrm{~cm}$ (Table 3). As in the Cerrado/Pantanal ecotone this period is characterized by low temperatures and rainfall, the use of this intercropping mode can be promising for cattle farmers due to its higher DM production, wherein the percentage of leaves is the main component.
Leucaena and pigeon pea, regardless of the form of cultivation, have the highest levels of crude protein (CP) for the entire plant and the leaves (Table 4) in rainy seasons, regardlles of the form of cultivation. Regardless of the cultivation, pigeon pea obtained the largest values of neutral detergent fiber (NDF) for the entire plant, while for leaves the elephant grass presented the highest means. Something similar happened to the mineral matter (MM), where the elephant grass (in intercropping or monocrop) had the highest averages for the entire plant and the 
leaves, there was also, a similarity between the forages. For the other features (culm and stems lower and larger than $1 \mathrm{~cm}$ ) there was no difference among the cultivation systems in terms of nutritional quality, which allows us to infer that evaluated intercropping arrangements are promising for the Cerrado/Pantanal ecotone.

Table 3. Mean values for the percentage of leaves, culms, senescent material, stems lower and larger than $1 \mathrm{~cm}$ of forage grass elephant (CE), Leucaena (L) and pigeon pea $(\mathrm{G})$ grown in monocrop and intercropping system during the dry season.

\begin{tabular}{lllllll}
\hline Forage & Leaf & Culm & Senescent material & Stem $<1 \mathrm{~cm}$ & Stem $>1 \mathrm{~cm}$ \\
\hline Elephant grass (EG) in monocrop & $25.9 \mathrm{bc}$ & $56.9 \mathrm{a}$ & $17.2 \mathrm{a}$ & - & - \\
Leucaena (L) in monocrop & $32.3 \mathrm{~b}-$ & $0.00 \mathrm{c}$ & $22.6 \mathrm{~b}$ & $41.9 \mathrm{a}$ \\
Pigeon pea (PP) in monocrop & $22.2 \mathrm{c}$ & - & $22.2 \mathrm{a}$ & $38.9 \mathrm{a}$ & $0.0 \mathrm{c}$ \\
Intercropping EG+L: Elephant grass & $21.1 \mathrm{c}$ & $63.4 \mathrm{a}$ & $15.5 \mathrm{a}$ & - & - \\
Intercropping EG+L: Leucaena & $33.3 \mathrm{~b}$ & - & $0.00 \mathrm{c}$ & $50.0 \mathrm{a}$ & $16.7 \mathrm{~b}$ \\
Intercropping EG+PP: Elephant grass & $24.7 \mathrm{c}$ & $57.3 \mathrm{a}$ & $18.0 \mathrm{a}$ & - & - \\
Intercropping EG+PP: Pigeon pea & $75.0 \mathrm{a}$ & - & $8.3 \mathrm{~b}$ & $16.7 \mathrm{~b}$ & $0.0 \mathrm{c}$ \\
\hline
\end{tabular}

Means followed by different letters in the column indicate significant differences according to Tukey's test at $5 \%$ probability.

Table 4. Mean values for the content of dry matter (DM), crude protein (CP), neutral detergent fiber (NDF) and mineral matter $(\mathrm{MM})$ of forage grass elephant $(\mathrm{CE})$, Leucaena $(\mathrm{L})$ and pigeon pea $(\mathrm{G})$ grown in monocrop and intercropping system during the rainy season.

\begin{tabular}{|c|c|c|c|c|}
\hline Forage & $\mathrm{DM}(\%)$ & $\mathrm{CP}(\%)$ & $\operatorname{NDF}(\%)$ & $\mathrm{MM}(\%)$ \\
\hline & \multicolumn{4}{|c|}{ Entire plant } \\
\hline Elephant grass (EG) in monocrop & $31.18 \mathrm{a}$ & $7.11 \mathrm{~b}$ & $60.81 \mathrm{bc}$ & $7.71 \mathrm{a}$ \\
\hline Leucaena $(\mathrm{L})$ in monocrop & $28.30 \mathrm{a}$ & $14.88 \mathrm{a}$ & $61.55 \mathrm{~b}$ & $6.08 \mathrm{~b}$ \\
\hline Pigeon pea $(\mathrm{PP})$ in monocrop & $30.07 \mathrm{a}$ & $13.63 \mathrm{a}$ & $68.92 \mathrm{a}$ & $5.21 \mathrm{~b}$ \\
\hline Intercropping EG+L: Elephant grass & $30.00 \mathrm{a}$ & $6.07 \mathrm{~b}$ & $59.36 \mathrm{bc}$ & $8.61 \mathrm{a}$ \\
\hline Intercropping EG+L: Leucaena & $21.45 \mathrm{~b}$ & $14.48 \mathrm{a}$ & $59.5 \mathrm{bc}$ & $6.00 \mathrm{~b}$ \\
\hline Intercropping EG+PP: Elephant grass & $27.81 \mathrm{a}$ & $6.59 \mathrm{~b}$ & $57.41 \mathrm{c}$ & $8.25 \mathrm{a}$ \\
\hline Intercropping EG+PP: Pigeon pea & \multicolumn{3}{|l|}{ Leaf } & $5.72 \mathrm{~b}$ \\
\hline Elephant grass (EG) in monocrop & $24.05 \mathrm{c}$ & $9.51 \mathrm{~b}$ & $71.85 \mathrm{a}$ & $8.23 \mathrm{ab}$ \\
\hline Leucaena $(\mathrm{L})$ in monocrop & $26.52 \mathrm{~b}$ & $23.40 \mathrm{a}$ & $44.97 \mathrm{~d}$ & $7.41 \mathrm{ab}$ \\
\hline Pigeon pea $(\mathrm{PP})$ in monocrop & $29.48 \mathrm{a}$ & $23.83 \mathrm{a}$ & $54.52 \mathrm{c}$ & $7.98 \mathrm{ab}$ \\
\hline Intercropping EG+L: Elephant grass & $23.56 \mathrm{c}$ & $9.29 \mathrm{~b}$ & $71.43 \mathrm{a}$ & $9.24 \mathrm{a}$ \\
\hline Intercropping EG+L: Leucaena & $26.42 \mathrm{~b}$ & $21.05 \mathrm{a}$ & $45.86 \mathrm{~d}$ & $7.14 \mathrm{~b}$ \\
\hline Intercropping EG+PP: Elephant grass & $23.02 \mathrm{c}$ & $10.43 \mathrm{~b}$ & $69.90 \mathrm{a}$ & $8.79 \mathrm{ab}$ \\
\hline Intercropping EG+PP: Pigeon pea & \multicolumn{3}{|l|}{ Culm } & $7.54 \mathrm{ab}$ \\
\hline Elephant grass (EG) in monocrop & $13.01 \mathrm{a}$ & $5.55 \mathrm{a}$ & $70.68 \mathrm{a}$ & $10.96 \mathrm{a}$ \\
\hline Leucaena (L) in monocrop & - & - & - & - \\
\hline Pigeon pea $(\mathrm{PP})$ in monocrop & - & - & - & - \\
\hline Intercropping EG+L: Elephant grass & $11.96 \mathrm{a}$ & $4.90 \mathrm{a}$ & $70.90 \mathrm{a}$ & $11.56 \mathrm{a}$ \\
\hline Intercropping EG+L: Leucaena & - & - & - & - \\
\hline Intercropping EG+PP: Elephant grass & $12.36 \mathrm{a}$ & $5.63 \mathrm{a}$ & $69.12 \mathrm{a}$ & $11.15 \mathrm{a}$ \\
\hline \multirow[t]{2}{*}{ Intercropping EG+PP: Pigeon pea } & & - & - & - \\
\hline & \multicolumn{4}{|c|}{ Stems lower than $1 \mathrm{~cm}$} \\
\hline Elephant grass (EG) in monocrop & - & - & - & - \\
\hline Leucaena (L) in monocrop & $30.80 \mathrm{a}$ & $6.74 \mathrm{a}$ & $76.89 \mathrm{a}$ & $5.15 \mathrm{a}$ \\
\hline Pigeon pea $(\mathrm{PP})$ in monocrop & $30.50 \mathrm{a}$ & $6.58 \mathrm{a}$ & $78.36 \mathrm{a}$ & $4.99 \mathrm{a}$ \\
\hline Intercropping EG+L: Elephant grass & - & - & - & - \\
\hline Intercropping EG+L: Leucaena & $29.38 \mathrm{a}$ & $5.70 \mathrm{a}$ & $77.87 \mathrm{a}$ & $4.53 \mathrm{a}$ \\
\hline Intercropping EG+PP: Elephant grass & - & - & - & - \\
\hline Intercropping EG+PP: Pigeon pea & $29.90 \mathrm{a}$ & $6.05 \mathrm{a}$ & $78.28 \mathrm{a}$ & $4.11 \mathrm{a}$ \\
\hline
\end{tabular}


Elephant grass (EG) in monocrop

Leucaena (L) in monocrop

Pigeon pea (PP) in monocrop

Intercropping EG+L: Elephant grass

Intercropping EG+L: Leucaena

Intercropping EG+PP: Elephant grass

Intercropping EG+PP: Pigeon pea
Stems larger than $1 \mathrm{~cm}$

$\begin{array}{llll}- & - & - & - \\ 28.43 \mathrm{a} & 5.26 \mathrm{a} & 81.20 \mathrm{a} & 3.99 \mathrm{a} \\ 31.11 \mathrm{a} & 3.99 \mathrm{~b} & 86.21 \mathrm{a} & 2.91 \mathrm{a} \\ - & - & - & - \\ - & - & - & - \\ - & - & - & - \\ - & - & - & -\end{array}$

Means followed by different letters in the column indicate significant differences according to Tukey's test at $5 \%$ probability.

Azevedo (1985) observed levels of CP, NDF and MM (10.6, 65.6, and 5.0\%, respectively) for the entire plant of the elephant grass. Garcia et. al., (1996), reported for the entire Leucaena plant values of $22.0,39.5$ and $8.0 \%$ for PB, FDN and MM, respectively, whereas Valadares Filho (2000), mentions values of $19.3,57.2$ and $5.4 \%$ for CP, NDF and MM, respectively. For pigeon pea, Pires et al. (2006) reported values of 22.4, 73.6 and $5.3 \%$ of $\mathrm{CP}, \mathrm{NDF}$ and MM, respectively for the entire plant. The protein levels found in Leucaena leaves show up similar to those observed by several authors, who found rates ranging from $17.1 \%$ to $25.9 \%$ (ALENCAR; GUSS, 1991; LOURENÇO et. al., 1992; RAMOS et. al., 1997; LOPES et. al., 1998).

In the dry seasons, the Leucaena and pigeon pea (in monocrop system) showed the highest values of $\mathrm{CP}$ in entire plant (Table 5). It was observed in all forage increased protein content in the leaf fraction, followed by the fraction pod and flower, in legumes. However, inverse results were observed in the fiber fraction, with higher NDF concentrations observed in the culm and stem of grass and legumes, respectively. Teodoro et al. (2007), verified for the same period in this region, levels of CP and NDF of 4, 6 and 1\%; and 73, 69 and $73 \%$ for entire plant, leaves and culm of elephant grass, respectively. Demeu et. al. (2007), during the same period, they observed for leucaena levels of CP and FDN of 16, 16, 4, 4 and 5\%; and of $36 ; 55 ; 79 ; 83$ and $24 \%$ for leaves, pod and flower, stem and entire plant, respectively. These values are similar to those observed in this trial. Pires et al. (2006), reported to tender branches and leaves of pigeon pea, levels of 22 and $74 \%$ of CP and NDF, respectively.

Table 5. Mean values for the content of dry matter (DM), crude protein (CP), neutral detergent fiber (NDF) and mineral matter $(\mathrm{MM})$ of forage grass elephant $(\mathrm{CE})$, Leucaena $(\mathrm{L})$ and pigeon pea $(\mathrm{G})$ grown in monocrop and intercropping system during the dry season.

\begin{tabular}{lllll}
\hline Forage & DM (\%) & CP (\%) & NDF (\%) & MM (\%) \\
\hline & Entire plant & & \\
Elephant grass (EG) in monocrop & $37.93 \mathrm{bc}$ & $3.29 \mathrm{c}$ & $65.21 \mathrm{a}$ & $5.47 \mathrm{~b}$ \\
Leucaena (L) in monocrop & $37.08 \mathrm{c}$ & $12.77 \mathrm{a}$ & $63.33 \mathrm{a}$ & $5.41 \mathrm{~b}$ \\
Pigeon pea (PP) in monocrop & $43.43 \mathrm{~b}$ & $10.95 \mathrm{ab}$ & $45.71 \mathrm{~b}$ & $6.64 \mathrm{ab}$ \\
Intercropping EG+L: Elephant grass & $39.55 \mathrm{bc}$ & $2.68 \mathrm{c}$ & $66.76 \mathrm{a}$ & $5.98 \mathrm{ab}$ \\
Intercropping EG+L: Leucaena & $41.07 \mathrm{bc}$ & $9.00 \mathrm{~b}$ & $63.86 \mathrm{a}$ & $5.00 \mathrm{~b}$ \\
Intercropping EG+PP: Elephant grass & $41.54 \mathrm{bc}$ & $3.43 \mathrm{c}$ & $64.69 \mathrm{a}$ & $5.04 \mathrm{~b}$ \\
Intercropping EG+PP: Pigeon pea & $52.18 \mathrm{a}$ & $10.00 \mathrm{~b}$ & $60.36 \mathrm{a}$ & $7.95 \mathrm{a}$ \\
& Leaf & & & \\
Elephant grass (EG) in monocrop & $30.16 \mathrm{~b}$ & $8.12 \mathrm{~d}$ & $76.01 \mathrm{a}$ & $8.11 \mathrm{~b}$ \\
Leucaena (L) in monocrop & $31.58 \mathrm{ab}$ & $24.45 \mathrm{a}$ & $30.77 \mathrm{~d}$ & $7.57 \mathrm{~b}$ \\
Pigeon pea (PP) in monocrop & $31.29 \mathrm{ab}$ & $22.24 \mathrm{ab}$ & $37.75 \mathrm{c}$ & $8.98 \mathrm{ab}$ \\
Intercropping EG+L: Elephant grass & $30.97 \mathrm{ab}$ & $6.99 \mathrm{~d}$ & $75.88 \mathrm{a}$ & $9.81 \mathrm{ab}$ \\
Intercropping EG+L: Leucaena & $36.95 \mathrm{ab}$ & $19.96 \mathrm{~b}$ & $34.00 \mathrm{c}$ & $8.21 \mathrm{~b}$ \\
Intercropping EG+PP: Elephant grass & $32.03 \mathrm{ab}$ & $8.44 \mathrm{~d}$ & $75.27 \mathrm{a}$ & $9.35 \mathrm{ab}$ \\
Intercropping EG+PP: Pigeon pea & $39.44 \mathrm{a}$ & $14.94 \mathrm{c}$ & $44.04 \mathrm{~b}$ & $11.88 \mathrm{a}$ \\
& Culm & & & \\
Elephant grass (EG) in monocrop & $26.22 \mathrm{a}$ & $2.05 \mathrm{a}$ & $79.77 \mathrm{a}$ & $5.90 \mathrm{a}$ \\
Leucaena (L) in monocrop & - & - & - & - \\
Pigeon pea (PP) in monocrop & - & - & - & - \\
Intercropping EG+L: Elephant grass & $29.10 \mathrm{a}$ & $1.80 \mathrm{a}$ & $81.31 \mathrm{a}$ & $6.27 \mathrm{a}$ \\
Intercropping EG+L: Leucaena & - & - & - & -
\end{tabular}


Intercropping EG+PP: Elephant grass Intercropping EG+PP: Pigeon pea

Elephant grass (EG) in monocrop Leucaena (L) in monocrop

Pigeon pea (PP) in monocrop Intercropping EG+L: Elephant grass Intercropping EG+L: Leucaena Intercropping EG+PP: Elephant grass Intercropping EG+PP: Pigeon pea

Elephant grass (EG) in monocrop Leucaena (L) in monocrop Pigeon pea (PP) in monocrop Intercropping EG+L: Elephant grass Intercropping EG+L: Leucaena Intercropping EG+PP: Elephant grass Intercropping EG+PP: Pigeon pea

Elephant grass (EG) in monocrop Leucaena $(\mathrm{L})$ in monocrop Pigeon pea (PP) in monocrop Intercropping EG+L: Elephant grass Intercropping EG+L: Leucaena Intercropping EG+PP: Elephant grass Intercropping EG+PP: Pigeon pea

$\begin{array}{llll}29.94 \mathrm{a} & 2.36 \mathrm{a} & 80.62 \mathrm{a} & 4.76 \mathrm{a} \\ - & - & - & - \\ \text { Stems lower than } 1 \mathrm{~cm} & & \\ - & - & - & - \\ 37.15 \mathrm{a} & 6.62 \mathrm{a} & 75.81 \mathrm{~b} & 5.69 \mathrm{a} \\ 37.21 \mathrm{a} & 5.48 \mathrm{a} & 72.48 \mathrm{c} & 5.88 \mathrm{a} \\ - & - & - & - \\ 42.78 \mathrm{a} & 4.80 \mathrm{a} & 78.94 \mathrm{a} & 3.67 \mathrm{~b} \\ - & - & - & - \\ 38.65 \mathrm{a} & 6.61 \mathrm{a} & 70.89 \mathrm{c} & 5.43 \mathrm{a} \\ \text { Stems larger than } 1 \mathrm{~cm} & & \\ - & - & - & - \\ 42.20 \mathrm{a} & 6.62 \mathrm{a} & 83.00 \mathrm{a} & 3.54 \mathrm{a} \\ 20.68 \mathrm{~b} & 2.54 \mathrm{~b} & 84.63 \mathrm{a} & 2.30 \mathrm{a} \\ - & - & - & - \\ 15.75 \mathrm{~b} & 3.79 \mathrm{~b} & 82.57 \mathrm{a} & 2.13 \mathrm{a} \\ - & - & - & - \\ 38.65 \mathrm{a} & 6.61 \mathrm{a} & 70.89 \mathrm{a} & 5.43 \mathrm{a} \\ \text { Pod and flower } & & \\ - & - & - & - \\ 26.26 \mathrm{a} & 20.62 \mathrm{a} & 41.11 \mathrm{a} & 6.61 \mathrm{a} \\ 26.07 \mathrm{a} & 26.39 \mathrm{a} & 43.23 \mathrm{a} & 5.53 \mathrm{a} \\ - & - & - & - \\ 10.04 \mathrm{~b} & 22.46 \mathrm{a} & 41.50 \mathrm{a} & 7.23 \mathrm{a} \\ - & - & - & - \\ 10.43 \mathrm{~b} & 26.07 \mathrm{a} & 41.51 \mathrm{a} & 5.60 \mathrm{a}\end{array}$

Means followed by different letters in the column indicate significant differences according to Tukey's test at $5 \%$ probability.

In the dry season it was found that the leaves fraction, regardless of evaluated forage showed the highest mineral content, followed by flower and pod fraction in legumes and stem in elephant grass. It can be seen also that the concentration of minerals in the elephant grass was also high in fraction stem, and hence the entire plant, there was also no influence of different cropping systems. In the leucaena, there were significant differences between the stems fractions (higher and smaller than $1 \mathrm{~cm}$ ). For the pigeon pea was the reverse, being observed a similarity in the mineral content in stems fractions.

\section{CONCLUSIONS}

In both seasons (rainy and dry), the forage grown in intercropping system showed higher dry matter production to monocrop system, with most of this production coming of elephant grass.

The intercropping elephant grass with the pigeon pea has the highest production of dry matter, while the intercropping elephant grass with Leucaena has better nutritional quality.

RESUMO: Os objetivos deste trabalho foram avaliar a produção de forragem e a qualidade nutricional do capim elefante, Leucaena e feijão guandu, cultivados de forma solteira ou em sistema de consórcio no ecótono Cerrado/Pantanal, em duas estações do ano (das águas e seca). O delineamento utilizado foi o inteiramente casualizado com cinco tratamentos e cinco repetições. Os tratamentos foram: capim elefante solteiro; Leucaena solteira; feijão gandu solteiro; consórcio capim elefante com Leucaena; consórcio capim elefante com feijão guandu. Na época das chuvas foram realizados três cortes em intervalos de 60 dias e na época da seca um único corte, com 180 dias. Na estação das chuvas, a biomassa produzida das forrageiras capim elefante, Leucaena e feijão guandu corresponderam, respectivamente, a 72, 64, $76 \%$ de toda a produção anual. No sistema de consórcio as forrageiras apresentaram um comportamento similar, com média de $72 \%$ da produção anual. Neste período a qualidade nutritiva das forrageiras também foi superior a época seca. No período seco, verificou-se menor produção de biomassa e uma redução na proporção de folhas, em todas as forrageiras, independentemente do sistema de cultivo. Em ambos os períodos (águas e seco), as forrageiras cultivadas em sistema de consórcio, apresentaram produção de matéria seca superior às cultivadas solteiras, sendo a maior parte desta produção 
oriunda do capim elefante. O consorcio do capim elefante com o feijão guandu apresenta a maior produção de matéria seca, enquanto o consórcio do capim elefante com a Leucaena possui melhor qualidade nutricional.

PALAVRAS-CHAVE: Cajanus cajan. Pennisetum purpureum. Leucaena leucocephala.

\section{REFERENCES}

ABOT, A. R.; FARIAS, E. B.; OLIVEIRA, M. V. M.; OLIVEIRA, D. P.; TORRES, F. E.; TEODORO, P. E.; RIBEIRO, L. P. Chemical-bromatological compositon of leucaena hay as function of drying and storage times. Bioscience Journal (Online), Uberlândia, v. 31, p. 1450-1457, 2015.

ALENCAR, J. A.; GUSS, A. Efeito da frequiência de corte sobre a produção de matéria seca e proteína bruta da cunhã (Clitoria ternatea) e da Leucaena (Leucaena leucocephala). Vitória: EMCAPA, 1991. (EMCAPA - Comunicado Técnico, n. 65).

AOAC - Association of Official Analytical Chemists. Official methods of analysis. 15.ed. Washington: AOAC, 1990.

AZEVEDO, P. B. M. Aspectos econômicos da produção agrícola do capim-elefante. Encontro de Energia do Meio Rural, Campinas, v. 3, p. 1-4, 2000.

CARNEIRO, M. S. S.; SOUZA, P. Z.; PEIXOTO, M. J. A.; SALES, R. O.; FEITOSA, J. V. Efeito do consórcio de capim-elefante com Leucaena na produção de forragem. Caatinga, Mossoró, v. 19, n. 1, p. 51-55, 2006.

GARCIA, G. W.; FERGUSON, T. U.; NECKLES, F. A.; ARCHIBALD, K. A. E. The nutritive value and forage productivity of Leucaena leucocephala. Animal Feed Science and Tecnology, Philadelphia, v. 60, p. 29-41, 1996. https://doi.org/10.1016/0377-8401(95)00922-1

LOPES, W. B.; SILVA, D. S.; PIMENTA FILHO, E. C.; SILVA, R. L.; DIAS, J. M. Q. Avaliação morfofisiológica e da produção de Leucaena em diferentes épocas do ano. In: $36^{\circ}$ Reunião Anual da Sociedade Brasileira de Zootecnia. Anais... Porto Alegre: SBZ, 1999. CD-ROM.

LOURENÇO, A. J.; MATSUI, E.; DELISTOIANOV, J.; BOIN, C.;BORTOLETO, O. Composição botânica da forragem disponível e da selecionada por bovinos em pastos de colonião e soja perene, com acesso aos bancos de proteína nas secas. Revista Brasileira de Zootecnia, Viçosa, v. 21, n. 4, p. 703-717, 1992.

OLIVEIRA, E. P.; SILVEIRA, L. P. O.; TEODORO, P. E.; ASCOLI, F. G.; TORRES, F. E. Efeito do sombreamento e do incrustamento de sementes sobre o desenvolvimento inicial de cultivares de Panicum maximum Jacq. Bioscience Journal (Online), Uberlândia, v. 30, p. 1682-1691, 2014.

PIRES A. J. V.; REIS, R. A.; CARVALHO, G. G. P.; SIQUEIRA, G. R.; BERNARDES, T. F.; ALMEIDA, A. C. R. E. O.; ROTH, M. T. R. Degradabilidade ruminal da matéria seca, da fração fibrosa e da proteína bruta de forrageiras. Pesquisa Agropecuária Brasileira, Brasília, v. 41, n. 4, p. 643-648, 2006.

https://doi.org/10.1590/S0100-204X2006000400014

QUEIROZ FILHO, J. L.; SILVA, D. S. Da; NASCIMENTO, I. S. Proução de matéria seca e qualidade do capim-elefante (Pennisetum purpureum Schum.) cultivar roxo em diferentes idades de corte. Revista Brasileira de Zootecnia, Viçosa, v. 29, n. 1, pg. 69-74, 2000.

R CORE TEAM. R: A language and environment for statistical computing. R Foundation for Statistical Computing, Vienna, Áustria, 2012. Disponível em: http://www.R-project.org/. Acesso em: 12 nov. 2012. 
RAMOS, G. M.; ITALIANO, E. C.; NASCIMENTO, M. P. S. C. B.; ARAUJO NETO, R. B. Recomendações sobre o cultivo da Leucaena na alimentação animal. Teresina: EMBRAPA, 1997. (Circular Técnica, n. 16).

SEIFFERT, N. F.; THIAGO, L. R. L. S. Legumineira, cultura forrageira para produção de proteína. Coronel Pacheco: EMBRAPA, 1983. (Circular técnica, n. 13).

TEODORO, A. L.; OLIVEIRA, M. V. M.; RUFINO JUNIOR, J. Avaliação da qualidade nutritiva da Leucaena e do capim elefante cultivados sozinhos ou em consórcio, recebendo níveis crescentes de adubação nitrogenada, durante o período de outono-inverno. In: Encontro de Zootecnistas. Anais... Londrina, PR: ZOOTEC 2007.

CD-ROM.

VALADARES FILHO, S. C.; MACHADO, P. A. S.; CHIZZOTTI, M. L. Tabelas Brasileiras de Composição de Alimentos para Bovinos, 2000. Disponível em: http://cqbal.agropecuaria.ws/webcqbal/index.php. Acesso em: 20 mar. 2015.

VAN SOEST, P. J.; ROBERTSON, J. B.; LEWIS, B. A. Methods for dietary fiber, neutral detergent fiber, and nonstarch polyssacarides in relation to animal nutrition. Journal of Dairy Science, Champaign, v. 74, n. 10, p. 3583-3597, 1991. https://doi.org/10.3168/jds.S0022-0302(91)78551-2 